\title{
Komparasi Buruh Gendong di Pasar Beringharjo dan Giwangan Yogyakarta
}

\author{
Noflin Thofir \\ Program Studi Ilmu Sosiologi, Universitas Widya Mataram \\ Email : yihen96381@goqoez.com
}

\begin{abstract}
Abstraksi
Penelitian ini bertujuan untuk melihat komparasi buruh gendong di Pasar Beringharjo dan Pasar Giwangan Yogyakarta. Penelitian ini dilakukan dengan metode penelitian kualitatif deskriptif. Teknikteknik yang digunakan dalam penelitian ini adalah wawancara, observasi, dan dokumentasi. Hasil penelitian menunjukkan bahwa: pertama, secara ekonomi, buruh gendong merupakan masyarakat yang menawarkan buruh gendong yang ditawarkan sangat membantu mobilitas pedagang dalam memberikan latar belakang ke bawah. Kedua, Secara pendidikan, buruh gendong hanya terdapat di SD, SMP, dan yang tidak bersekolah. Ketiga, Secara umur, buruh gendong memiliki umur hampir rata-rata yaitu mulai dari 35 tahun sampai 70 tahun, bahkan lebih, Keempat, Jasa yang pelayanan pengangkutan barang kepada konsumen, dan konsumen merasa dimudahkan dengan jasa buruh gendong. Buruh gendong selalu memanjakan dengan pasar tradisional. Buruh gendong merupakan perempuan yang berprofesi menggendong barang-barang bawaan yang berupa barang dagangan. Dan adanya ketidakadilan dalam memberikan upah terhadap pekerja. Buruh gendong hanya mendapatkan upah dari hasil gendongannya.
\end{abstract}

Kata Kunci: Komparasi, Buruh Gendong, Perempuan, Pasar

\begin{abstract}
This study aims to determine the comparison of the 'buruh gendong' in Beringharjo Market and Giwangan Market in Yogyakarta. This research was conducted by using descriptive qualitative research methods. The techniques used in this research are interviews, observation, and documentation. The results of the study show that: first, economically, the carrying workers are the people who offer the 'buruh gendong' who are offered to help the mobility of traders in providing a downward background. Second, in terms of education, the 'buruh gendong' are only found in SD, SMP, and those who do not attend school. Third, in terms of age, the 'buruh gendong' have an almost average age, ranging from 35 years to 70 years, even more. Fourth, services that provide goods transportation services to consumers, and consumers feel facilitated by the services of 'buruh gendong'. They always indulge in traditional markets. The 'buruh gendong' are women whose profession is to carry goods in the form of merchandise. And the existence of injustice in providing wages to workers. They only get wages from what they carry.
\end{abstract}

Keywords: Comparation, Buruh Gendong, Woman, Traditional Market

\section{Pendahuluan}

Sesuai dengan Pasal 1 UU No.13 tahun 2003, tenaga kerja adalah modal utama dalam pelaksanaan pembagunan nasional untuk mencapai kesejahteraan. Sementara itu pembagian golongan pekerja dibagi dalam 2 kelompok besar, yakni pekerja laki-laki dan pekerja perempuan. 
Beberapa dekade terakhir, pemahaman masyarakat tentang pembagian kelompok pekerja perempuan telah mulai bergeser dari sudut pandang partriarki yang dulu sangat mendominasi. Perempuan tidak hanya sebagai ibu rumah tangga dan pendidik dalam keluarga saja, tetapi perempuan ikut serta dalam mencari nafkah (Sukardi, 2002). Upaya ini tak lain adalah untuk memenuhi kebutuhan hidup mereka dan keluarganya serta meningkatkan kesejahteraan hidup (Ridjal, 2004).

Dalam realitasnya, ideologi partriarki yang telah mengakar kuat di masyarakat masih banyak diyakini oleh sebagian masyarakat. Hal ini telah menjadi sebuah hegemoni atau kesadaran palsu yang tertanam dalam diri manusia yang disebabkan oleh pemaksaan ideologi oleh kelompok dominan, sehingga menjadi sebuah kewajaran. Sebuah riset yang dilakukan sebelumnya oleh Loekman Soetrisno (2001) menemukan fakta, perempuan tidak dapat memilih pekerjaan dan menuntut upah yang memadai karena mereka tidak memiliki keterampilan yang memadai pula. Kondisi modern saat ini mau tak mau menuntut para calon-calon tenaga kerja untuk memiliki pendidikan dan ketrampilan kerja yang bagus. Sedangkan, sisi lainnya ada faktor yang membuat para perempuan kesulitan mendapatkan peluang untuk turut berkontestasi sebagai pekerja di sektor publik, yakni kemiskinan (Hamalik, 2004). Banyak keluarga yang berasal dari pedesaan lebih mengutamakan anak laki-laki mereka untuk bersekolah dari pada perempuan. Sebab ada sebuah anggapan bahwa laki-laki kelak akan menjadi pemimpin dan tulang punggung bagi keluarganya setelah menikah. Para perempuan pun pada akhirnya memilih untuk berusaha sendiri sebisa mereka untuk mencukupi kebutuhannya dan keluarganya setelah menikah. Pekerjaan sebagai buruh gendong merupakan solusi yang banyak dipilih oleh perempuan, di karenakan buruh gendong tidak memerlukan pendidikan tinggi dan keahlian khusus, dan selain itu perempuan masih dapat melakukan pekerjaannya tanpa harus meninggalkan perannya sebagai ibu rumah tangga.

Buruh berbeda dengan pekerja. Pekerja adalah orang yang bekerja di suatu badan milik swasta atau pemerintah yang diberikan upah berupa gaji yang sesuai dengan peraturan yang diundang dan pekerja yang dapat menerima gaji, gaji yang ambil bisa mingguan atau bulanan. Sedangkan buruh, mereka adalah orang yang bekerja pada usaha perorangan yang tidak seimbang, berupah upah dan diberikan secara harian. Sistem kerja biasanya dilakukan secara harian dan borongan. Upah ditetapkan oleh kesepakatan bersama antara majikan dan pekerja / buruh. Para buruh gendong sehari-harinya mencari nafkah melalui cara menjual jasanya dengan tenaga 
tubuhnya tanpa memiliki keahlian. Keadaan seperti ini sangat beresiko besar bagi perempuan, sebab mereka menjual jasa dengan menggendong barang bawaan dagangan. Kegiatan menggendong sendiri merupakan aktivitas fisik yang bertentangan dengan imej perempuan. Dalam beberapa teori gender, segala aktivitas fisik seringkali dilekatkan pada sifat maskulin lakilaki, sebaliknya perempuan dilekatkan dengan segala aktivitas yang halus seperti memasak dan merawat anak. Padahal sesungguhnya baik laki-laki dan perempuan semuanya selalu melakukan aktivitas fisik setiap harinya, hanya saja yang membedakan adalah seberapa besar tingkat aktivitas fisik tersebut. Kegiatan menggendong yang dilakukan oleh para buruh gendong perempuan ini termasuk dalam aktivitas fisik yang memiliki tingkat besar, karena di dalamnya terjadi aktifitas mengangkat, menjunjung, membawa, dan meletakkan barang dagangan yang jumlahnya banyak.

Kebanyakan buruh gendong memiliki latar belakang kehidupan yang berasal dari keluarga menengah ke bawah. Mereka menjadi buruh gendong karena keterbatasan lapangan pekerjaan di tempat di mana mereka berasal. Buruh gendong Pasar Beringharjo dan Pasar Giwangan merupakan pasar tradisional yang banyak memiliki buruh gendong yang berasal dari luar kota Yogyakarta. Buruh gendong Pasar Beringharjo ada yang berasal dari Sleman, Bantul, Wonosari, Gunung Kidul, Kulon Progo, bahkan ada juga yang datang dari Klaten. Sedangkan buruh gendong Pasar Giwangan ada yang berasal dari Gunung Kidul, Sleman, Bantul, Sukoharjo, Purworejo, Kulon Progo, Wonosari, bahkan ada juga yang datang dari Solo. Para perempuan dari berbagai daerah tersebut datang dari desa ke kota untuk mencari pekerjaan sebagai buruh gendong.

Di Yogyakarta terdapat dua pasar yang dipilih oleh para buruh gendong untuk bekerja, yakni Pasar Beringharjo dan Pasar Giwangan. Kedua pasar tradisional ini dipilih karena tempatnya sangat terbuka bagi orang asing, banyak yang terjadi transaksi jual-beli antara pedagang dan pembeli, serta transaksi tawar menawar barang dan jasa. Pasar tradisional memiliki tipe bangunan pasar yang sangat tradisional yang terdiri dari los pasar, kios pasar, dan memiliki ruangan terbuka. Biasanya para buruh gendong memulai aktivitasnya ketika pasar tersebut di buka. Mereka tidak hanya melayani pembeli yang berbelanjaan di pasar saja, melainkan juga melayani pedagang pasar. Kita dapat menjumpai buruh gendong seperti di kios pasar dan los pasar. Kios pasar juga terdapat berbagai macam pedagang yang berjualan, sedangkan los pasar juga tidak ada satu pedagang, melainkan banyak pedagang. Pedagang yang banyak di sesuaikan dengan pasar yang 
sangat banyak. Pasar yang besar sudah jelas memiliki banyak pedagang, sedangkan pasar yang kecil secara otomatispun memiliki pedagang yang sedikit pula.

Dalam perspektif gender, proporsi tenaga kerja laki-laki dan perempuan di sektor informal adalah laki-laki $60 \%$ dan perempuan hanya $40 \%$, dan proporsi tenaga kerja perempuan di sektor informal mencakup 70\% dari keseluruhan tenaga kerja perempuan (Khotimah, 2009). Permasalahn mendasar lainnya yang masih terjadi sampai saat ini yaitu adanya diskriminasi terjadinya perbedaan perlakuan yang diterima oleh perempuan dalam dunia kerja. Pada kenyataannya perempuan di sektor informal masih banyak yang mendapatkan perlakuan yang berbeda antara lain seperti perbedaan gaji, perbedaan proses seleksi, dan promosi yang dikaitkan dengan status perkawinan pekerja perempuan. Perlakuan semacam ini menyebabkan adanya diskriminasi terhadap perempuan. Lebih khususnya pada buruh gendong perempuan di Pasar Beringharjo dan Pasar Giwangan Yogyakarta. Apalagi kebanyakan dari mereka berstatus sebagai ibu rumah tangga (pekerja domestik) dan sebagai pencari nafkah di luar rumah (pekerja publik). Riset ini bertujuan untuk mengetahui komparasi buruh gendong di Pasar Beringharjo dan Pasar Giwangan Yogyakarta dilihat dari sisi karakteristiknya, pengguna jasa, motivasi, dan penampilan.

\section{Metode}

Riset ini merupakan studi deskriptif kualitatif yang bermaksud untuk memahami suatu fenomena dalam konteks sosial secara alamiah dengan mengedepankan proses interaksi komunikasi yang mendalam antara peneliti dengan yang diteliti (Moleong, 2002). Penulis memilih metode deskriptif kualitatif dengan maksud untuk mengetahui dan mengambarkan secara mendalam tentang Profil Buruh Gendong dan mengkomparasikan Buruh Gendong di Pasar Beringharjo dan Pasar Giwangan Yogyakarta. Teknik pengumpulan data menggunakan wawancara, observasi, dan dokumentasi. Peneliti memilih 11 orang informan, terdiri dari 3 orang buruh gendong Pasar Beringharjo, 3 orang buruh gendong Pasar Giwangan, 2 orang pedagang Pasar Beringharjo, 2 orang pedagang Pasar Giwangan, dan 1 orang pengurus Yasanti. Sampel ini lebih cocok digunakan untuk penelitian kualitatif, atau penelitian-penelitian yang tidak melakukan generalisasi.

Analisis data dalam penelitian kualitatif dilakukan sejak memasuki lapangan, selama dilapangan, dan setelah dilapangan. Penelitian ini untuk mendapatkan dan mengeksplorasikan data yang diperoleh secara deskriptif analisis. Dalam aktivitasnya sebagai Buruh Gendong di Pasar 
Beringharjo dan Pasar Giwangan Yogyakarta. Hal ini dilakukan untuk mengembangkan teori yang dibangun dari data yang sudah didapatkan di lapangan. Peneliti melakukan penjelajahan, kemudian dilakukan pengumpulan data yang mendalam, mulai dari observasi dan penyusunan laporan. Riset ini difokuskan dan dilihat dari sudut pandang informan, sehingga dapat memperoleh data secara utuh dan menyeluruh terkait dengan fenomena yang diteliti, dan sekaligus dapat menangkap sesuatu hal yang tersembunyi. Analisis data dalam riset ini merupakan sebuah proses mencari dan menyusun secara sistematis dengan mengurutkan dan mengorganisasikannya kedalam suatu pola, kategori, dan uraian dasar data yang diperoleh dari wawancara, observasi, dan dokumentasi (Moleong, 2002).

\section{Hasil dan Pembahasan}

\section{Profil Buruh Gendong}

Eksistensi buruh gendong sudah ada sejak jaman dulu dan masih dipertahankan hingga sekarang. Dimana ada pasar besar biasanya ada para buruh gendong yang turut mencari nafkah di sana. Dengan kata lain buruh gendong sudah menjadi salah satu budaya yang masih dipertahankan oleh masyarakat dari jaman duluh hingga sekarang ini. Buruh gendong menawarkan jasa berupa mengangkut barang dagangan dari penjual dan pembeli barang dagangan di pasar. Para perempuan buruh gendong ini rata-rata berusia 35-70 tahun dan memiliki profesi utama sebagai ibu rumah tangga.

Para buruh gendong perempuan ini melontarkan panggilan nama endong-endong saat mereka yang bekerja menjual di gendong. Pekerjaan yang dilakukan oleh para buruh gendong perempuan ini buka semata-mata untuk keperluan sendiri, melainkan untuk memenuhi kebutuhan keluarga. Tidak hanya sedikit kebutuhan yang harus dipenuhi oleh pekerja buruh gendong, selain makan dan minum, mereka harus menambung untuk keperluan sekolah anak-anak mereka. Pekerjaan yang mereka lakukan tidak sebanding dengan apa yang mereka gendong setiap harinya, gendongan-gendongan tersebut setiap harinya berjumlah yang banyak dan berat. Rata-rata setiap gendongan mulai dari 20-72 kg bahkan lebih. Upah buruh gendong kalau dilihat hampir semua sama, mulai dari Rp. 4.000,- hingga Rp 9.000,- setiap gendongnya.

Menurut para informan riset, mereka memilih bekerja sebagai buruh gendong karena tidak mempunyai pendidikan yang cukup untuk mendukung bekerjaan di sektor informan. Hal ini dapat 
diketahui ketika ditanyakan kepada buruh gendong yang menyatakan tidak sempat mengenyam pendidikan di bangku sekolah. Sebenarnya jika pendidikan mereka cukup, keinginan untuk bekerja di sektor informal sangat kuat. Ini sangat terkait dengan jumlah penghasilan yang relatif lebih banyak dengan pengeluaran tenaga yang relatif sedikit dibanding pekerjaan di sektor informan sebagai buruh gendong. Bagi masyarakat yang tidak biasa melakukan pekerja seperti ini beranggapan bahwa ini merupakan pekerjaan yang tidak manusiawi. Mengapa dikatakan tidak manusiawi, karena pekerjaan yang nereka lakukan tidak sesuai sekali dengan upah atau bayaran yang mereka terima. Upah atau bayaran sangat kecil tetapi beban yang digendong lebih banyak dan berat.

\section{Komparasi Buruh Gendong di Pasar Beringharjo dan Pasar Giwangan}

\section{Buruh Gendong Pasar Beringharjo}

Pasar Beringharjo merupakan pasar tradisional tetua dan terbesar di kota Yogyakarta. Paasar Beringharjo hampir mampu menyediakan apapun keinginan pengunjung. Banyak yang menyebut beringharjo sebagai pasar tradisional terindah di jawa, tapi yang pasti beringharjo memiliki keterkaitan dengan Sejarah Kraton Jogja dan budaya jawa, dan juga menjadi ikon wisata Jogja seperti halnya malioboro. Terdapat empat orang pedagang yang diwawancarai, masingmasing pasar terdapat dua orang yang diwawancarai yaitu Ibu Dede, ibu Winda, Ibu Ema, dan Ibu Darmi. Keempat informan ini suka menggunakan jasa buruh gendong untuk mengangkat barangbarang dagangan mereka. Upah yang diberikanpun sesuai dengan harga biasanya, tergantungan pada pedagang-pedagang tersebut.

"Saya suka memakai jasa buruh gendong mbak. Adanya buruh gendong pekerjaan saya sangat mudah, mudahnya itu saya bersama suami tidak susah-susah lagi mengangkat barang dagangan yang ada. Kami tinggal membayar buruh gendong untuk membantu kami mengangkat barang dagangan kami." (Hasil wawancara dengan ibu Dede salah seorang pedagang di Pasar Beringharjo, 29-01-2020, pukul 10.30 WIB).

"Bukan hanya sering memakai jasa mereka mbak. Malahan saya punya langganan mbak, saya juga sering kerja sama dengan orang-orang kulakan di tempat bongkar muatan, langsung disalurkan ke buruh gendong untuk menggunakan jasanya. (Hasil wawancara dengan ibu Winda salah seorang pedagang di Pasar Beringharjo, 29-01-2020, pukul 14.00 WIB).

"Supaya mempermudah saya juga mbak. Dengan adanya buruh gendong saya tidak perlu repot-repot lagi ke sana kemari mencari dan membawa barang dagangan saya sendiri. Saya biasanya dibantu sama suami dan saudarah-saudarah saya mbak." (Hasil wawancara dengan ibu Erma salah seorang pedagang Pasar Giwangan, 03-02-2020, pukul 18.00 WIB). 
"Saya sangat bersyukur dengan adanya buruh gendong mbak. Sangat membantu sekali mbak, jadi dagangan saya itu bisa langsung dibawah." (Hasil wawancara dengan ibu Darmi salah seorang pedagang Pasar Giwangan, 03-02-2020, pukul 19.20 WIB).

Pada umumnya buruh gendong berasal dari berbagai daerah yaitu Sleman, Wonosari, Gunung Kidul, Bantul, dan Kulon Progo. Keputusan mereka untuk bekerja sebagai buruh gendong, dikarnakan lapangan kerja ditempat asal mereka terlalu susah. Seperti yang diungkapkan oleh dua orang buruh gendong yang bertinggal jauh dan kedua buruh gendong dari asal daerah yang sama yaitu Kulon Progo. Dari kedua buruh gendong ini, ibu Sukma memilih untuk tidak pulang ke rumah tapi lebih memilih untuk tinggal di sekitar pasar. Berbeda lagi dengan ibu Rohimin, ia lebih memilih pulang kembali ke rumah.

\footnotetext{
"Saya lebih memilih gak pulang mbak. Ingin pulang sih mbak tapi saya pikir-pikir lagi, soalnya saya udah gak mudah lagi untuk naik-turun pick up mbak, wong saya sudah tua, jadi mending saya tinggal di dekat pasar. Tinggalnya didekat selter ATM BRI dekat toko progo itu mbak, malah disitu saya bisa mengumpulkan upah yang saya dapat ya walaupun tidak banyak tapi alhamdullia saya bersyukur mbak". (Hasil wawancara, 30-01-2020, jam 10.00, bersama ibu Sukma, buruh gendong campuran).

"Kalau saya mau gak mau saya harus pulang ke rumah mbak, soalnya saya sudah di tunggu oleh suami dan anak-anak saya mbak. Pulangnya juga gak sendiri-sendiri mbak tapi pulangnya bersama dengan rombongan, kendaraan yang pakai bersama rombongan itu truk dan pick up mbak". (Hasil wawancara, 3001-2020, jam 11.00, bersama ibu Rohimin, buruh gendong campuran).
}

Hubungan ini tidak saja terlihat pada sesama buruh gendong, melainkan mereka juga harus meluangkan waktu bersama keluarga mereka di rumah. Walaupun jarak yang mereka tidak dekat tapi apa daya mereka harus melakukan semua itu demi keluarga. Untuk menghemat biaya yang ada tidak semua buruh gendong harus pulang ke rumah, melainkan mereka ada yang memilih untuk tinggal.

\section{Buruh Gendong Pasar Giwangan}

Pasar Giwangan merupakan pasar yang beroperasi 24 jam. Buruh gendong di Pasar Giwangan bekerja dengan waktu yang berbeda-beda, ada yang memilih untuk bekerja saat pagi, siang, sore, dan pada subuh hari. Sebagian dari buruh gendong memilih untuk berangkat sore dan subuh, dan berharap dapat penghasil yang lebih banyak karena aktivitas di pasar sangat ramai pada jam tersebut. Rata-rata buruh gendong Pasar Giwangan adalah perantauan yang bersal dari luar kota. Buruh gendong perempuan di Pasar Giwangan biasa disebut endong- endong. Istilah Buruh Gendong tidak sama dengan buruh yang lainnya seperti buruh tani, buruh cuci, dan buruh bangunan. Sebutan untuk laki-laki dan perempuan sangat berbeda. Laki-laki disebut buruh kuli 
sedangkan untuk perempuan disebut buruh gendong. Barang yang biasanya di gendong yaitu buahbuahan, dan sayur-sayuran, karena Pasar Giwangan merupakan pasar induk buah dan sayur, dan buruh gendongnya juga terbagai menjadi dua buruh gendong yaitu buruh gendong khusus buah dan buruh gendong khusus sayur.

Pekerjaan yang dilakukan oleh buruh gendong ini bukan merupakan pekerjaan yang gampang dan mudah, tetapi pekerjaan ini membutuhkan cara-cara tersendiri, dan dengan beban yang sangat berat. Beban yang diangkat oleh buruh gendong tidak sesuai dengan ukuran tubuhnya, namun mereka sangat kuat dalam mengangkut barang bawaan dengan beban yang berat. Berat beban bervariasi ada yang 10-60 kg dan adapula yang mencapai 72-90 kg. Upah yang didapatkan oleh buruh gendongpun tidak menentu. Ada yang membayar dengan harga Rp. 5000,- sampai Rp. 7000,-. Apabila buruh gendong memiliki langganan tetap, bisa mendapatkan upah sebesar Rp. 10.000 sampai Rp. 12.000. mengangkat barang bawaan juga mereka harus membungkuk setelah itu baru menggendong barang bawaannya. Jarak yang ditempuh oleh buruh gendong buah dan sayur ini, bisa mencapai 100-300 m bahkan lebih.

Buruh Gendong yang berada di Pasar Giwangan Yogyakarta mayoritas adalah warga yang berurbanisasi. Minimnya kesempatan kerja dan terbatasnya lahan pertanian yang digerap oleh mereka di pedesaan mendorong masyarakat agar menciptakan lapangan kerja yang baru. Buruhburuh gendong ini berasal dari berbagai daerah yaitu Solo, Bantul, Sleman, Gunung Kidul, Sukoharjo, Wonosari, dan Purworejo. Kebanyakan dari mereka yang tinggal jauh lebih memilih untuk tidak pulang ke rumah, melainkan mereka memilih untuk tinggal di selter pasar, dan kos yang berdekatan dengan pasar, hal tersebut dilakukan agar bisa mengumpulkan hasil yang mereka dapatkan (uang) dan dapat menghemat biaya transportasi. Seperti yang dikatakan oleh dua orang buruh gendong yang berbeda tempat yaitu Gunung Kidul (Ibu Rohim) dan Bantul (Ibu Soraya).

\footnotetext{
"Saya lebih memilih tinggal di selter pasar mbak, kalau saya bolak-balikjogja-gunung kidul uang saya bisa habis hanya di transportasi, disamping itu mbak, saya udah gak kuat harus bolak-balik ke rumah tiap hari". (Hasil wawancara, 02-02-2020, jam 11.00, bersama ibu Rohim-buruh gendong sayur).

"Kalau tinggal di pasar kan tidak bayar mbak, paling cuman bayar biaya mandi sama nyuci, dan makan untuk hari-harinya. Untuk tempat tinggalnya sudah disediakan oleh kantor Yasanti mbak. Dan bagusnya saya bisa tabung dari hasil gendongan saya dan bisa dibawah pulang, kalau sudah waktunya saya pulang mbak." (Hasil wawancara 02- 02-2020, jam 14.00, bersama ibu Soraya-buruh gendong buah).
}

Selter pasar merupakan salah satu fasilitas yang disediakan oleh Yasanti (Yayasan Annisa Swasti Yogyakarta). Alasan mereka memilih untuk tinggal diselter pasar atau kos dikarenakan 
untuk menghemat biaya transportasi, dan bisa ditabung dari hasil menggendong, dan juga menjaga kondisi tubuh agar tidak dan lelah. Tinggal diselter pasar hanya membayar biaya makan, minum, mandi, nyuci, dan keperluan lainnya. Sedangkan buruh gendong yang rumahnya dekat dengan pasar biasanya disebut pelajo. Pelajo adalah buruh gendong yang melakukan perjalanan pulangpergi dari rumah ke tempat kerjanya.

Salah satu pengurus Yasanti yang selalu turun langsung mendampingi para buruh gendong yaitu Ustand Farhan. Ustand Farhan diberi tanggung jawab oleh Yasanti untuk mengajarkan agama pada buruh gendong baik itu di Pasar Beringharjo maupun di Pasar Giwangan. Masalah sholat itu pribadi masing-masing buruh gendong, saya hanya mengajarkan pengajian yang diadakan pada setiap hari jumat. Ustand Farhan menyatakan bahwa beliau tidak mengajar pengajian sendiri tapi dibantu oleh beberapa orang santri. Pada Pasar Beringahrjo terdapat 2 orang santri, sedangkan pada Pasar Giwanganpun sama terdapat 2 orang santri.

Terdapat kegiatan yang dilakukan oleh Yasanti. Kegiatan yang dilakukan adalah pengajian ritun. Pengajian rutin dihadiri oleh buruh gendong. Buruh gendong akan diajarkan mengaji oleh Pak Ustand sendiri maupun diajarkan oleh beberapa santri yang terlibat dalam pengurus Yasanti. Terdapat salah gambar pengajian rutin yang dilakukan oleh Yasanti kepada buruh gendong.

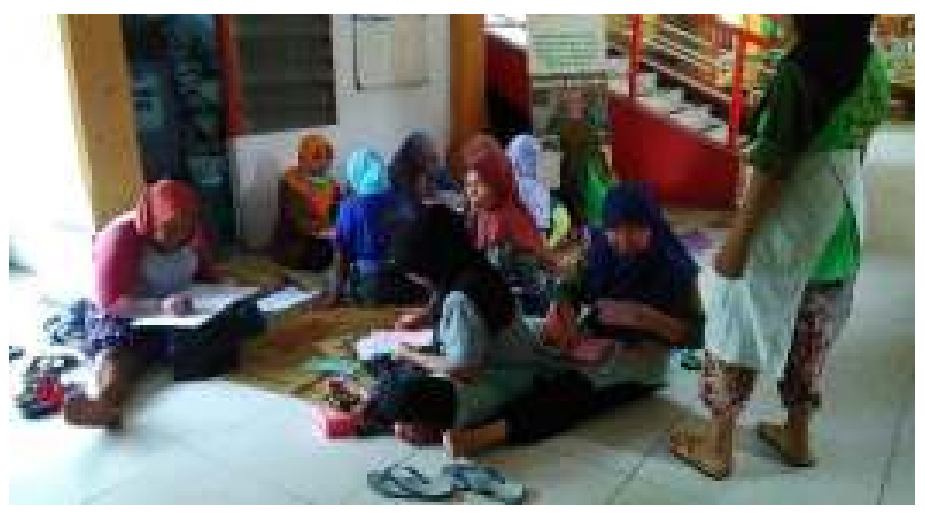

Gambar 1. Kegiatan mengaji para buruh gendong (sumber: Hasil Dokumentasi Penulis 2020).

Buruh gendong Pasar Giwangan biasanya memakai stagen pada perutnya agar tetap terlihat kuat dalam menggendong barang bawaan, dan membawa perlengkapan peralatan seperti kain selendang, jarit lurik, dan srumbung. Kain selendang adalah kain yang membantu buruh gendong untuk menggendong barang bawaan mereka, jarit lurik adalah sebagai pelengkap peralatan kerja seperti salah satunya yaitu tali untuk mengingat barang bawaan yang dilapisi dengan kain 
selendang, dan srumbung adalah alat bantu penopang beban (barang bawaan yang terbuat dari anyaman bambu) yang mereka gendong.

Buruh gendong perempuan ini tidak memiliki pendidikan, dan tidak memiliki keahlian maupun ketrampilan apapun, untuk itu mengakibatkan mereka memilih pekerjaan informal. Ini merupakan salah satu pekerjaan yang hanya menghandalkan tenaga. Berdasarkan hasil wawancara peneliti menemukan temuan bahwa buruh gendong yang berlatar belakang keluarga menengah ke bawah memiliki daya dorong untuk pergi ke kota untuk mengubah nasibnya, karena lapangan kerja yang ada di desa mereka sangat sedikit dan semakin sedikit pemilik lahan pertanian yang membutuhkan tenaga kerja. Adapun alasan yang mereka berikan adalah mereka hanya Lulusan Sekolah Dasar bahkan ada yang ada tidak bersekolah sama sekali, sehingga mereka lebih memilih untuk bekerja sebagai buruh gendong. Walaupun bekerja sebagai buruh gendong, tetapi tanggung jawab sebagai seorang istri dan ibu tidak pernah mereka tinggalkan.

Buruh gendong yang memiliki tanggung jawab sebagai ibu rumah tangga dan memiliki tugas yang begitu sangat besar terhadap keluarganya. Terdapat kewajiban utama yaitu mengurus suami dan anak-anak sebelum berangkat kerja, sebagai ibu rumah tangga, dan membantu mencari nafkah. Buruh gendong perempuan yang bekerja, terutama bagi yang sudah berumah tangga. Untuk mereka, pekerjaan sebagai buruh gendong memberikan kesempatan supaya dapat melakukan pekerjaan diluar rumah. Secara kondisi sosial ekonomi menunjukkan suatu keadaan individu atau keluarga dalam masyarakat. Dimana keadaan tersebut mencerminkan posisi individu atau keluarga yang bersangkutan. Posisi tersebut bersangkutan dengan berbagai faktor yaitu umur, pendidikan, jam kerja, status, dan asal daerah.

Selanjutnya penulis juga menemukan 4 poin utama dari hasil analisis komparasi buruh gendong di Pasar Beringharjo dan Pasar Giwangan tersebut, terdapat beberapa poin penting yang dijelaskan pada tabel berikut:

Tabel 1. 4 Poin Komparasi Buruh Gendong Pasar Beringharjo dan Pasar Giwangan

\begin{tabular}{lll}
\hline & Pasar Beringharjo & Pasar Giwangan \\
\hline Karakteristik & $\begin{array}{l}\text { Lebih memilih barang bawaan apa saja dan } \\
\text { tidak memilih-milih. Banyak mengangkat } \\
\text { barang bawaan campuran (berbagai jenis } \\
\text { barang). }\end{array}$ & $\begin{array}{l}\text { terbagi menjadi dua yaitu buruh gendong } \\
\text { buah-buahan dan buruh gendong sayur- } \\
\text { sayuran }\end{array}$ \\
\hline
\end{tabular}




\begin{tabular}{|c|c|c|}
\hline Motivasi & \multicolumn{2}{|c|}{$\begin{array}{l}\text { Perempuan-perempuan yang bekerja sebagai buruh gendong di Pasar Beringharjo dan Pasar } \\
\text { Giwangan merupakan pekerja yang didasari kemampuan sendiri dan ada juga yang diajak } \\
\text { teman, keluarga, untuk mencari rejeki yang halal. Kebanyakan dari mereka memiliki } \\
\text { kesamaan yaitu alasan ekonomi dan membantu suami mencari nafkah. Alasan ekonomi } \\
\text { merupakan hal yang paling mendorong seseorang untuk mencari pekerjaan. }\end{array}$} \\
\hline Penampilan & \multicolumn{2}{|c|}{$\begin{array}{l}\text { Buruh gendong pada kedua pasar ini memiliki kesamaan dalam gaya penampilan. Mereka } \\
\text { menggunakan kain selendang dan memiliki fisik yang kuat. Untuk penampilan, buruh } \\
\text { gendong hanya memiliki penampilan sederhana saja. Dibilang rapi juga tidak, menarik juga } \\
\text { tidak, melainkan mereka memiliki daya tarik tersendiri yaitu adalah mereka mempunyai fisik } \\
\text { yang kuat dalam mengangkat barang bawaan dengna jumlah beban yang banyak dan berat. } \\
\text { Dengan kata lain keduanya memiliki kesamaan yaitu cara berpakaian yang sederhana, tidak } \\
\text { memakai make-up, hanya memakai kain gendong sebagai alat bantu. }\end{array}$} \\
\hline Pengguna Jasa & $\begin{array}{l}\text { Para buruh gendong berjalan berkeliling } \\
\text { sambil mencari gendongan untuk diangkut dan } \\
\text { menghasilkan upah. Gendongannya juga } \\
\text { bermacam-macam ada yang berupa barang } \\
\text { belanjaan pembeli, disuruh pedagang, } \\
\text { pedagangnya juga bermacam- macam. } \\
\text { Terdapat berbagai macam pedagang dengan } \\
\text { begitu para buruh gendong tidak kesulitan } \\
\text { menunggu adanya tawaran gendongan dari } \\
\text { pembeli maupun pedagang yang ada di Pasar } \\
\text { Beringharjo. }\end{array}$ & $\begin{array}{l}\text { Para buruh gendong di Pasar Giwangan } \\
\text { tidak perlu berjalan mengelilingi pasar untuk } \\
\text { menawarkan jasanya, melainkan mereka } \\
\text { hanya berdiri dan menunggu dimana para } \\
\text { pedagang buah dan sayur menawarkan jasa } \\
\text { mereka. }\end{array}$ \\
\hline
\end{tabular}

\section{Kesimpulan.}

Berdasarkan hasil analisis, penulis menyimpulkan beberapa temuan. Pertama, buruh gendong selalu dikaitkan pasar tradisional. Buruh gendong adalah perempuan yang berprofesi menggendong barang bawaan yang berupa dagangan. Barang bawaan yang di gendong oleh buruh gendong adalah dagangan dari penjual ke pembeli, dan dari penjual utama ke pembeli grosiran untuk dijual kembali. Kedua, terdapat tiga faktor yang mempengaruhi buruh gendong yaitu:

a. Faktor ekonomi: latar belakang buruh gendong merupakan masyarakat yang menengah bawah. Faktor ekonomi yang semakin meningkat maka kebutuhan hiduppun semakin tinggi.

b. Faktor tingkat pendidikan: hampir rata-rata buruh gendong perempuan ini memiliki tingkat pendidikan yang sangat rendah. Rendahnya pendidikan para buruh gendong ini, menyebabkan mereka memutuskan untuk bekerja sebagai buruh gendong di pasar tradisional.

c. Faktor keterampilan: dalam melakukan pekerjaan, seorang pekerja harus memiliki adanya suatu keterampilan dalam mendukung pekerjaannya. Akan tetapi berbeda lagi dengan para 
buruh gendong perempuan ini, mereka tidak memiliki keterampilan, melainkan hanya mengandalkan tenaga mereka.

Ketiga, adanya ketidakadilan dalam memberikan upah terhadap pekerja. Buruh gendong hanya mendapatkan upah dari hasil gendongannya, upahnyapun tergantungan pada pedagang dan pembeli yang memakai jasa mereka. Upah buruh gendong sangat kecil dan tidak sesuai dengan gendongannya. Keempat, Pasar Beringharjo dan Pasar Giwangan merupakan pasar tradisional yang tertua di kota Yogyakarta. Pasar-pasar ini sama-sama memiliki pekerja buruh gendong, dan para buruh gendong ini bukan saja berasal dari dalam kota Yogyakarta, melainkan terdapat juga para buruh gendong perempuan tersebut ada yang berasal dari luar kota Yogyakarta. Kelima, ketika sektor informal memberikan peluang pada perempuan maka peran perempuan keluarga cenderung bergeser. Perempuan tidak hanya berperan sebagai ibu rumah tangga, tetapi juga sebagai penanggung jawab dalam memenuhi kebutuhan hidup keluarga. Keenam, dalam hal ini buruh gendong tidak mengalami ketertekanan mental dalam bekerja, karena didukung oleh adanya kebersamaan di antara para buruh gendong dan terbangunnya hubungan yang baik antara sesama buruh gendong, maupun yana memakai jasa mereka. Inilah yang membuat para buruh gendong tetap bekerja sebagai buruh gendong.

\section{Daftar Pustaka}

Hamalik, Oemar. 2004. Pendidikan Guru Berdasarkan Pendekatan Kompetensi. Jakarta: Bumi Aksara.

Khotimah, Khusnul. 2009. Diskriminasi Gender Terhadap Perempuan Dalam Sektor Pekerjaan. STAIN Purwokerto. Jurnal Studi dan Anak. Diakses tanggal 05 fenruari 2020, pukul 18.00 WIB

Loekman Soetrisno. 2001. Kemiskinan, Perempuan, dan Pemberdayaan. Yogyakarta: Kanisius.

Moleong, Lexy. 2002. Metodologi Penelitian Kualitatif. Bandung: PT. Remaja Rosdakarya.

Sukardi, Dewa Ketut. 2002. Pengantar Pelaksanaan Program Bimbingan dan Konseling di Sekolah. Jakarta: Rineka Cipta.

Ridjal, Fauzie. 2004. Dinamika Gerakan Perempuan di Indonesia. Yogyakarta: Tiara Wacana. 